\title{
Civic capital and support for the welfare state
}

Roy Cerqueti, Fabio Sabatini, Marco Ventura

\section{EERI Research Paper Series No 13/2017}

ISSN: 2031-4892

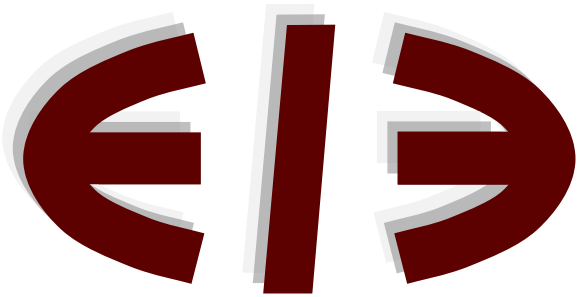

EERI

Economics and Econometrics Research Institute

Avenue Louise

1050 Brussels

Belgium

Tel: +32 22719482

Fax: +32 22719480

www.eeri.eu 


\title{
Civic capital and support for the welfare state
}

\author{
Roy Cerqueti $^{a}$, Fabio Sabatini $^{b}$, Marco Ventura $^{c}$ \\ ${ }^{* a}$ Department of Economics and Law - University of Macerata, Italy \\ Email: roy.cerqueti@unimc.it \\ ${ }^{b}$ Department of Economics and Law - Sapienza University of Rome, Italy \\ Email: fabio.sabatini@uniroma1.it \\ ${ }^{c}$ ISTAT, Italian National Institute of Statistics, Rome, Italy \\ Email: mventura@istat.it
}

October 12, 2017

\begin{abstract}
We model how the interplay between tax surveillance institutions and civic capital shapes taxpayers' support for welfare state. We show that, when tax surveillance is tight, rational civic-minded individuals express greater support for welfare spending than uncivic ones. We provide empirical evidence of these preferences using data from Italy, a country that has long posed a puzzle for public economists for its limited civic capital and large welfare state.
\end{abstract}

Keywords: welfare state, redistribution, tax surveillance, trust, civic capital, social capital.

JEL Classification: H10, H53, D63, D69, Z1.

\section{Introduction}

In these times of economic crisis and public finance distress, the issue of welfare state legitimacy has become a central theme in the public debate. The size of the welfare state ultimately depends on citizens' support, which, according to standard economic reasoning, might be basically determined by self-interest. Some authors suggested that government size crucially depends on civic capital, which restrains free-rider problems and bureaucratic failures (Rothstein, 2009; Bergh and Bjørnskov,

\footnotetext{
${ }^{*}$ We are indebted to Joshua Angrist, Marc Sangnier, Maurizio Franzini and Marcella Nicolini for comments and suggestions. The paper also benefited from conversations with Eiji Yamamura and Luca Zamparelli. Usual disclaimers apply.
} 
2011; Bjørnskov and Svendsen, 2013). In line with the literature on civic capital (e.g. Putnam et al., 1993; Antoci et al., 2012; Guiso et al., 2016) ${ }^{1}$, Algan et al. (2016) distinguished individuals between "civic" and "uncivic" taxpayers, to show that uncivic citizens express higher support for the welfare state because they expect to benefit from it without bearing its costs. Civic-minded individuals, on the other hand, are less favourable to big-sized welfare states because they fear free-rider problems.

Algan et al.'s model helps understand how Mediterranean countries can have large welfare states despite their low levels of civic capital and trust. We add to this literature by showing that taxpayers' preference for welfare spending varies according to their civic-mindedness in unexpected ways also depending on institutions. When tax surveillance is perceived as tight, civic-minded taxpayers rationally express higher support for the welfare state than uncivic citizens. ${ }^{2}$ Our model extends the framework proposed by Algan et al. (2016) by making the assumption that, when taxpayers consider whether to support higher government spending or not, they also take into account the efficiency and tightness of tax surveillance, i.e. the probability of being caught and sanctioned by enforcement institutions in case of tax evasion. As the tightness of surveillance increases, civic-minded individuals will be more confident that everyone will pay taxes and that free riding and rent seeking activities will be limited, resulting in higher support for welfare spending. On the other hand, uncivic individuals will find a large-sized welfare state less attractive. Higher levels of civic capital at the macro level strengthen the support for large welfare states in either type of individual.

We use the notion of civic capital in the sense proposed by Guiso et al. (2011; 2016) as those persistent and shared beliefs that help a group overcome the free rider problem in the pursuit of socially valuable outcomes. This form of capital has both a micro and a macro dimension. At the micro level, it takes the form of those norms that, among other things, lead the individual to behave prosocially, thereby discouraging free riding and rent seeking behaviours. At the macro level, civic capital derives from the sharing of the same norms. ${ }^{3}$

\footnotetext{
${ }^{1}$ See Sabatini (2009) and Guiso et al. (2011) for a review of the literature

${ }^{2}$ Hereafter, we will use civic and civic-minded as synonyms for sake of readability.

3 There may be doubt whether social capital - and civic capital, in particular - is an individual or a collective construct. In the sociological literature, it is commonly agreed that it is both. According to Bourdieu (1986) and
} 
We then test the predictions of the model using cross-sectional micro data provided by the Bank of Italy in its Survey on Household Income and Wealth (SHIW). To operationalize the concept of civic capital in the empirical analysis we follow Guiso et al. (2011; 2016) and use indicators of the extent to which individuals dislike actions of free riding and rent seeking. To provide consistent estimates despite the endogeneity of individuals' civic-mindedness we use a procedure proposed by Wooldridge (2002). This approach serves to cope with the absence of traditional identifying information by exploiting instruments derived from a nonlinear first-stage. We are aware this identification strategy is not as straightforward and transparent as a random natural experiment. However, it is anyway preferable to a basic OLS-based approach as it shares with experiment-based IV strategies the same estimator, which at least is proved to be consistent, implying that, given the validity of instruments, the two procedures at least provide the same result in large samples (Wooldridge, 2002).

The main conclusions of the empirical analysis are derived from the coefficient of the interacted term between taxpayers' civic capital and their perception of the probability of being caught and sanctioned in case of tax evasion, which we use as a proxy for the perceived efficiency of surveillance institutions. The empirical analysis shows that civic-minded individuals are significantly less likely to support the welfare state. Interacting our indicator of civic capital with the perceived efficacy of tax surveillance, however, reveals that when surveillance is regarded as tight, civic-minded individuals manifest a significantly stronger support for the welfare state in respect to uncivic ones.

These theoretical and empirical findings have important policy implications, suggesting that tightening tax surveillance could induce a more truthful revelation of the preferences of civic-minded citizens that could affect taxpayers' preference for redistribution, with effects on tax morale, the outcomes of electoral competitions and, ultimately, public spending.

\footnotetext{
Coleman (1988), social capital is basically an individual resource. The sharing of this resource, on the other hand, allows formal or informal groups of individuals to pursue shared goals. Bourdieu (1980) argues that actors might use social relations - which are often developed on the basis of a common belief - as means to increase their ability to advance personal interests and improve well-being. Coleman (1988) considers social capital as a resource that, while inherent in the structure of relations between actors, basically serves to "facilitate certain actions of actors, whether persons or corporate actors, within the structure" (p. 98). Reviews of these aspects social capital can be found in Coleman (1990), Fine (2001), Sabatini (2007).
} 
Our study bridges three strands of literature. The first deals generically with the economic outcomes of social capital dimensions. This body of studies empirically analyses how trust, civicness, and networks influence prosocial behavior (Sapienza et al., 2013), tax morale (Feld and Frey, 2002; Frey and Torgler, 2007; Andriani, 2015), regulation (Aghion et al., 2010), financial development (Guiso et al., 2004), trade (Guiso et al., 2009), and economic growth (Algan et al., 2010; Algan and Cahuc, 2014; Bigoni et al., 2016) just to name a few.

The second strand investigates the roots of citizens' preference for redistribution in relation to self- and other-regarding motivations, such as the taxpayers' future income and mobility prospects, the perceived equality of opportunities, and feelings of social rivalry (e.g. Meltzer and Richard, 1981; Piketty, 1995; Benabou and Ok, 2001; Fong, 2011; Corneo and Gruner, 2002), as well as possible feelings of empathy prompted by repeated social interactions (Yamamura, 2012; Sabatini et al., 2014). The third strand of the literature studies the determinants of the size of the welfare state. Overall, this body of research suggests that trust could reinforce the welfare state because trusting taxpayers may be less concerned with the free riding problem intrinsically connected with universal and simple access to public goods and services (Rothstein, 2002; Bergh and Bjørnskov, 2011; Bjørnskov and Svendsen, 2013; Daniele and Geys, 2015). Algan et al. (2016) remarkably innovated this literature revealing the twin peaks relationship between the country's level of trust and the size of the welfare state and explaining it as a consequence of dishonest citizens' stronger preference for redistribution.

We add to these fields of studies in substantive ways. We provide an empirically testable prediction of how surveillance institutions interact with civic capital in determining taxpayers' support for the welfare state. In testing the predictions of the model, we differentiate ourselves from previous literature by using a rich dataset from Italy - a country that has long posed a puzzle for public economists for its limited civic capital and large welfare state More specifically, we exploit detailed information on taxpayers' opinions about the hypothetical role and the preferred extension of welfare state schemes (such as those related to healthcare and pensions) and about their perception of the efficiency of tax enforcement institutions, which was not accounted 
for in previous empirical studies. We also try to go beyond the basic OLS-based approach by implementing a procedure aimed to correct the endogeneity issues that usually bias the analysis of individual preferences and opinions.

The rest of the paper is organized as follows: section 2 presents the model and illustrates its predictions. Section 3 is devoted to the description of our data and empirical strategy. Section 4 tests the predictions of the model at the individual level and provides an interpretation of results. Section 5 concludes.

\section{Theoretical model}

We start the theoretical analysis by modeling how the interplay between civic capital and surveillance institutions shapes support for the welfare state. This part of the analysis extends the model developed by Algan et al. (2016).

We consider a continuum of individuals of measure one, and partition them according to their civic-mindedness. Assume that $\alpha \in[0,1]$ is the share of civic individuals, and the remaining $1-\alpha$ the share of uncivic ones. As in Algan et al. (2016), all individuals share the same preferences over consumption, $c$, and the utility function is logarithmic, i.e.: $u(c)=\log (c)$.

Each individual produces a certain amount $y>0$ of consumption goods with probability $\pi$, and a lower level $y_{0}<y$ with probability $1-\pi$.

Those who produce amounts $y_{0}$ of consumption goods are entitled to welfare benefits. Agents producing $y$ must pay a tax, $t$, to finance such benefits $b$. However, productive taxpayers can cheat both on taxes and on welfare benefits, by declaring a lower amount of production and then claiming welfare benefits they are not actually entitled to. Following Algan et al. (2016) we call these individuals "uncivic". Civic individuals, on the other hand, neither cheat on taxes nor claim benefits they are not entitled to: they always declare their true level of production and - when their production is $y$ - they pay the tax $t$. At this point, we extend the framework of Algan et al. (2016) by making the plausible assumption that enforcement institutions not only monitor taxpayers' level of production but also have the power to inflict penalties on tax evaders. 
Tax surveillance specifically concerns those who declare lower amounts of production, $y_{0}<y$, and claim welfare benefits. When an inspection reveals that their true level of production is $y$, the surveillance institution imposes a fine $M$, requires the payment of the tax $t$, and withdraws the welfare benefits. The existence of surveillance institutions is a deterrent to free riding and rent seeking behaviours. An uncivic individual declares $y_{0}$ (i.e. the lower level of production) and claims benefits she is not entitled to with a positive probability $1-p$. The probability of an inspection is $1-q$, and the inspection entails a final payoff for the uncivic individuals of $y-t-M$, while the uncivic individual who is not subject to inspection obtains $y+b$.

We first analyse the optimal support for the welfare state from civic and uncivic individuals.

Following Algan et al (2016), we write the budget constraint of the government as follows:

$$
\pi t[\alpha+p(1-\alpha)]=[(1-\pi)+\pi(1-p)(1-\alpha)] b .
$$

The explicit form of the expected utility $U$ differs among civic and uncivic individuals. Taxpayers rationally choose the tax and the benefits that maximize their utility: $U=U(t, b)$. Specifically, we have:

$$
U(t, b)= \begin{cases}U_{\text {civic }}(t, b), & \text { for civic individuals; } \\ U_{\text {uncivic }}(t, b), & \text { for uncivic individuals }\end{cases}
$$

where

$$
U_{\text {civic }}(t, b)=\pi \log (y-t)+(1-\pi) \log \left(y_{0}+b\right)
$$

and

$U_{\text {uncivic }}(t, b)=\pi[p \log (y-t)+(1-p) q \log (y+b)+(1-p)(1-q) \log (y-t-M)]+(1-\pi) \log \left(y_{0}+b\right)$.

It is important to note that the deterrent provided by enforcement institutions only affects the utility of uncivic individuals, as civic-minded ones will refrain to cheat on 
taxes and benefits anyway. The optimization problem for the individual then is

$$
\max _{t, b} U(t, b)
$$

with the budget constraint (1), being $U(t, b)$ defined as in (3) (civic individuals) or as in (4) (uncivic individuals).

The constrained optimization problem (5)-(1) can be solved by introducing the Lagrangian $L$ as:

$$
L(t, b, \lambda)=U(t, b)+\lambda\{\pi t[\alpha+p(1-\alpha)]-[(1-\pi)+\pi(1-p)(1-\alpha)] b\},
$$

where $\lambda$ is the Lagrange multiplier.

The first order conditions are:

$$
\left\{\begin{array}{l}
\frac{\partial L(t, b, \lambda)}{\partial t}=\frac{\partial U(t, b)}{\partial t}+\lambda \pi[\alpha+p(1-\alpha)]=0 \\
\frac{\partial L(t, b, \lambda)}{\partial b}=\frac{\partial U(t, b)}{\partial b}-\lambda[(1-\pi)+\pi(1-p)(1-\alpha)]=0 \\
\frac{\partial L(t, b, \lambda)}{\partial \lambda}=\pi t[\alpha+p(1-\alpha)]-[(1-\pi)+\pi(1-p)(1-\alpha)] b=0
\end{array}\right.
$$

In what follows we are going to separately analyze the two cases of civic and uncivic individuals.

\subsection{Civic individuals}

By (3) and (6), the system of the first order conditions in (7) becomes:

$$
\left\{\begin{array}{l}
-\frac{\pi}{y-t}+\lambda \pi[\alpha+p(1-\alpha)]=0 \\
\frac{1-\pi}{y_{0}+b}-\lambda[(1-\pi)+\pi(1-p)(1-\alpha)]=0 \\
\pi t[\alpha+p(1-\alpha)]-[(1-\pi)+\pi(1-p)(1-\alpha)] b=0
\end{array}\right.
$$

Solving system (8) allows obtaining the optimal tax as:

$$
t_{c i v i c}=(1-\pi)-\frac{[1-\pi+\pi(1-p)(1-\alpha)] y_{0}}{\alpha+p(1-\alpha)}
$$

The optimal benefit $b_{\text {civic }}$ can immediately be derived by substituting $t=t_{\text {civic }}$ of (9) into the budget constraint - the third equation of system (8)-. 
As suggested in Algan et al. (2016), the support for the welfare state can intuitively be captured by the ratio of consumption of unproductive individuals, $y_{0}+b$, over consumption of productive individuals, $y-t$, chosen by civic individuals. As such ratio increases, agents want more welfare spending. Formally, we define:

$$
\rho_{\text {civic }}:=\frac{y_{0}+b_{\text {civic }}}{y-t_{\text {civic }}}=\frac{[\alpha+p(1-\alpha)](1-\pi)}{1-\pi+\pi(1-p)(1-\alpha)}
$$

being the second equality obtained by substituting the values $t_{\text {civic }}$ and $b_{\text {civic }}$ in the definition of $\rho_{\text {civic }}$ (first equality).

To emphasize the role of civic capital in determining individuals' support for the welfare state we consider the dependence of $\rho$ on $\alpha$ and write $\rho_{\text {civic }}$ as $\rho_{\text {civic }}=\rho_{\text {civic }}(\alpha)$, where $\alpha$ is the share of civic-minded individuals in the population of taxpayers.

The following result holds true:

Proposition 1. It is $\rho_{\text {civic }}^{\prime}(\alpha) \geq 0$, for each $\alpha \in[0,1]$.

Proof. A straightforward computation gives

$$
\rho_{\text {civic }}^{\prime}(\alpha)=\frac{(1-\pi)\{1-\pi+\pi(1-p)[1+p(1-\alpha)]\}}{[1-\pi+\pi(1-p)(1-\alpha)]^{2}},
$$

and the sign of the right-hand side of (11) is positive.

We notice that $\pi \neq 1$ leads to $\rho_{\text {civic }}^{\prime}(\alpha)>0$, while when $\pi=1$, then $\rho_{\text {civic }}^{\prime}(\alpha)=0$. This means that the higher the share of civic individuals, the stronger the support for the welfare state from civic-minded individuals. Civic individuals, in fact, will be less concerned with the possible free riding and rent seeking activities by uncivic fellow citizens. In addition, as the share of civic individuals in the population grows, the probability that public officials are corrupt decreases. This prediction is consistent with Algan et al. (2016) and, more in general, with the insights provided by the literature on trust and welfare state, which suggests that the size of the welfare state and citizens' support for it are positively associated with the share of the population that can be trusted (e.g. Kumlin and Rothstein, 2005; Bergh and Bjørnskov, 2011). 


\subsection{Uncivic individuals}

By plugging (4) into (7), we have:

$$
\left\{\begin{array}{l}
-\frac{\pi p}{y-t}-\frac{\pi(1-p)(1-q)}{y-M-t}+\lambda \pi[\alpha+p(1-\alpha)]=0 \\
\frac{\pi(1-p) q}{y+b}+\frac{1-\pi}{y_{0}+b}-\lambda[(1-\pi)+\pi(1-p)(1-\alpha)]=0 \\
\pi t[\alpha+p(1-\alpha)]-[(1-\pi)+\pi(1-p)(1-\alpha)] b=0
\end{array}\right.
$$

The system (12) admits solution, which will be denoted as $\left(t_{\text {uncivic }}, b_{\text {uncivic }}\right)$, for $\lambda=$ $\lambda_{\text {uncivic. }}$ The explicit form of $t_{\text {uncivic }}$ and $b_{\text {uncivic }}$ are not needed here. In fact, by the first and second equation of (12), we can directly write the ratio between benefits and taxes, in order to analyze the support of individuals for the welfare state. We obtain:

$\rho_{\text {uncivic }}:=\frac{y_{0}+b_{\text {uncivic }}}{y-t_{\text {uncivic }}}=\frac{\rho_{\text {civic }}}{p} \cdot\left(\frac{\pi(1-p) q\left(y_{0}+b_{\text {uncivic }}\right)}{(1-\pi)\left(y+b_{\text {uncivic }}\right)}+1\right)-\frac{(1-p)(1-q)\left(y_{0}+b_{\text {uncivic }}\right)}{p\left(y-M-t_{\text {uncivic }}\right)}$.

We show that, if the fine is high enough, then support for the welfare state is stronger in civic individuals than in uncivic ones. This claim is proved in the following:

Proposition 2. Assume that

$$
M>M^{*}:=y-t_{\text {uncivic }}-\frac{(1-\pi)(1-p)(1-q)\left(y_{0}+b_{\text {uncivic }}\right)\left(y+b_{\text {uncivic }}\right)}{\rho_{\text {civic }}\left[\pi q(1-p)\left(y_{0}+b_{\text {uncivic }}\right)+(1-\pi)\left(y+b_{\text {uncivic }}\right)\right]} .
$$

Then $\rho_{\text {uncivic }}(\alpha)<\rho_{\text {civic }}(\alpha)$, for each $\alpha \in[0,1]$.

Proof. The proof is a direct consequence of formula (13).

Proposition 2 deepens the result obtained by Algan et al. (2016), namely that uncivic individuals support the welfare state more than their civic-minded fellow citizens. In fact, if we make the plausible assumption that surveillance institutions can inflict penalties, uncivic individuals will take into account the deterrent of the penalty in their optimization problem. As a result, civic individuals will demand more welfare than uncivic ones.

More specifically, civic individuals will be more confident that antisocial behaviours will be not only detected but also properly punished by enforcement institutions. On 
the other hand, dishonest citizens will find extensive and universal welfare programs less attractive, in addition to fearing the prospect of paying both a fine and the due taxes. As expected, support for the welfare state increases in both civic and uncivic citizens with the share of civic individuals.

\subsubsection{A remark on uncivic individuals when there is no punishment for tax evasion}

In this case there is no punishment for tax frauds and we fall in the framework of Algan et al. (2016), where $M=0$ (and condition (14) does not hold).

The utility can be written as follows:

$$
U_{\text {uncivic }}(t, b)=\pi[p \log (y-t)+(1-p) \log (y+b)]+(1-\pi) \log \left(y_{0}+b\right) .
$$

By using this utility function in the optimization problem (5) with the budget constraint (1), we obtain that the first order conditions in (7) are:

$$
\left\{\begin{array}{l}
-\frac{\pi p}{y-t}+\lambda \pi[\alpha+p(1-\alpha)]=0 \\
\frac{\pi(1-p) q}{y+b}+\frac{1-\pi}{y_{0}+b}-\lambda[(1-\pi)+\pi(1-p)(1-\alpha)]=0 \\
\pi t[\alpha+p(1-\alpha)]-[(1-\pi)+\pi(1-p)(1-\alpha)] b=0
\end{array}\right.
$$

By solving system (16) we obtain

$$
\rho_{\text {uncivic }}^{(0)}(\alpha):=\frac{y_{0}+b_{\text {uncivic }}^{(0)}}{y-t_{\text {uncivic }}^{(0)}}=\frac{\rho_{\text {civic }}}{p} \cdot\left(\frac{\pi(1-p)\left(y_{0}+b_{\text {uncivic }}^{(0)}\right)}{(1-\pi)\left(y+b_{\text {uncivic }}^{(0)}\right)}+1\right),
$$

where the superscript (0) stands for "case with $M=0$ ".

Being

$$
\frac{1}{p} \cdot\left(\frac{\pi(1-p)\left(y_{0}+b_{\text {uncivic }}^{(0)}\right)}{(1-\pi)\left(y+b_{\text {uncivic }}^{(0)}\right)}+1\right)>1,
$$

we obtain that $\rho_{\text {uncivic }}^{(0)}(\alpha)>\rho_{\text {civic }}(\alpha)$, for each $\alpha \in[0,1]$. As expected, this result is in line with Algan et al. (2016). 


\section{Empirical evidence}

In this section, we test the predictions of the model at the individual level. Summarizing, the model predicts that: i) if institutions can inflict penalities, civic individuals display higher support for the welfare state than uncivic ones; ii) when penalties are removed, the opposite of prediction i) holds true and uncivic individuals show higher support for the welfare state. To test these predictions, we use Two-Stage Least Squares, TSLS, where the dependent variable is an indicator of individuals' support for the welfare state, and the main explanatory variables are individual civic capital and its interaction with the perceived tightness of tax surveillance. Both the two main explanatory variables are instrumented with the fitted probability from two nonlinear first-stages, one each, which provide us with consistent estimates, as explained in Wooldridge (2002). Our data and empirical strategy are described in detail in the following subsections.

\subsection{Data}

The data are taken from the 2004 wave of the SHIW, which is conducted every two years by the Bank of Italy. The sample includes about 8,000 households and is representative of the Italian population at the national and regional level (Bank of Italy, 2010). ${ }^{4}$ The sample was drawn in two stages (municipalities and households), with the stratification of the primary sampling units (municipalities) by region and demographic size. Within each stratum, the municipalities in which interviews would be conducted were selected to include all those with a population of more than 40,000 inhabitants (self-representing municipalities), while the smaller towns were selected on the basis of probability proportional to size (Bank of Italy, 2004). The individual households to be interviewed were then selected randomly. In the 2004 wave of the survey, a special section on "public spirit and taxation" was included in the questionnaire, in which respondents were asked to give their opinions on the tax system. We measure support for the welfare state using the following question: "Considering the Government's need to guarantee public services, please say which statement is closest to your own opinion: (please give only one answer): i) The Government's

\footnotetext{
${ }^{4}$ SHIW data can be downloaded from the Bank of Italy's website at the url: http://bit.ly/shiw2004.
} 
duty is to provide all citizens with as many public services as possible (e.g. school, healthcare, pensions, etc.) even if it means heavy taxes. ii) The Government has some unavoidable expenses for social welfare, which should be covered by taxes and duties, increasing these as and when necessary. iii) Taxation is too high, so if there is not enough money, expenses should be reduced by cutting back services iv) The Government should raise the bare minimum in taxes and duties to cover absolutely essential public services (e.g. defense, justice, the police, etc.) and leave the rest to private initiative". Our indicator of support for the welfare state is given by a binary variable which takes value 1 if the respondent's opinion is closest to statement i) or ii) and 0 otherwise. This variable is similar to the indicators commonly used by the literature to measure the individual support for redistribution (e.g. Fong, 2001; Alesina and La Ferrara, 2005; Guiso et al., 2006; Algan et al., 2016). Algan et al. (2016), for example, measure support for the welfare state through the score given by respondents to the following statement: "Incomes should be made more equal" versus "We need larger income differences as incentives" in the World Values Survey (WVS), which specifically refers to respondents' preference for redistribution. ${ }^{5}$ Guiso et al. (2006) measure support for redistribution through the 7-points score given by WVS respondents to the statement: "Some people think the government in Washington ought to reduce the income differences between the rich and the poor, perhaps by raising the taxes of wealthy families or by giving income assistance to the poor. Others think that the government should not concern itself with reducing this income differences". Alesina and La Ferrara (2005) measure the optimal size of redistributive schemes preferred by rational taxpayers through the score given by General Social Survey respondents to the statement: "Should the government reduce income differences between rich and poor?". In respect to these measures, our indicator of support for the welfare state is slightly refined as it explicitly asks respondents to focus on government spending for social welfare. As in Algan et al. (2016), higher levels of preferred spending are related to higher ratios of the consumption of unproductive individuals, $y_{0}+b$, over the consumption of productive individuals, $y-t$ preferred by

\footnotetext{
${ }^{5}$ More specifically, the WVS requires respondents to give a 10 points score to their opinion, where 10 means they agree completely with the statement on the right. Algan et al. (2016) employ a different dependent variable, relying on a more specific question regarding support for the welfare state, in a separate regression exploring the role of perceived trustworthiness.
} 
civic and uncivic individuals (see equations 10 and 13).

To measure civic capital, similarly to Algan et al. (2016), we follow Guiso et al. (2011) and focus on those values that induce people to dislike actions aimed at obtaining private benefits at high social costs. "For instance, people's opinions about cheating on taxes, free riding on public goods, cutting in line, littering and similar behaviours can all be good indicators of the prevalence of norms of morality and thus of people's willingness to internalize the public good. The common features across all these measure is that they are value judgments on activities that result in the appropriation of (possibly limited) private benefits at the expense of (possibly much larger) costs imposed on other members of society" (p. 17). Guiso et al. (2011) suggest using questions like those reported in the WVS about the perceived justifiability of free riding and rent seeking behaviors such as avoiding a fare on public transport and cheating on taxes whenever possible. In this paper we use responses to the question: "Which of the following situations do you think are always justifiable, never justifiable, or justifiable to some extent? Please give your answer on a scale from 1 to 10, 1 being "never justifiable" and 10 being "always justifiable", and the numbers in between indicating various degrees of agreement. i) Not paying for your ticket on public transport. ii) Keeping money you obtained by accident when it would be possible to return it to the rightful owner (for example, if you found a wallet with the owner's name and address, or if you were given too much change at the supermarket check-out). iii) Not leaving your name for the owner of a car you accidentally scraped while parking. Therefore, such a structure of the responses captures higher civicness for lower values of the response. In order to have higher values representing higher civicness we have inverted the answers scale. Our indicator of civic capital is the mean of the (inverted) scores given by respondents to the three statements.

As in Algan et al. (2016), this indicator is appropriate for testing the relationships described in equations 10 and 13 in that it allows to detect how support for the welfare state varies in relation to changes in the civic-mindedness of individuals. The aspect of tax surveillance that matters in determining agents' optimal taxes and benefits is the perceived tightness of enforcement institutions, which in the model is expressed by the penalty, $M$, inflicted to tax evaders and by the probability of tax 
inspection, 1-q. Given the definition of $M^{*}$ in Proposition 2, we have that an increase in $1-q$ lowers the threshold $M^{*}$ above which agents internalize the penalty, $M$, possibly inflicted by surveillance institutions in their optimization problem, thereby making uncivic individuals demanding less welfare and civic individuals supporting more redistribution. Therefore, Proposition 2 implicitly allows using the probability of inspection, instead of $M^{*}$, for discussing the implications of the model. To measure this perception we use the question: "In your opinion, what are the chances of someone being picked for a tax inspection?" on a five points scale, where 1 means "Very high" and 5 means "Practically non-existent". In this case too, the scale has been inverted in order to have increasing values measuring higher probabilities of being caught. In all the specifications we included controls for gender, age, household size, household income, work status and we accounted for regional effects, education and civil status.

\subsection{Empirical strategy}

From an empirical point of view, answering the question whether civic individuals have a greater or lower support for the welfare state, as compared to uncivic ones, is a difficult task for a number of reasons. First, there are obvious endogeneity problems, as both civicness and support for the welfare state may be driven by common unobservable attitudes such as altruism. Other-regarding attitudes, for example, can codetermine both civic-mindedness and support for the welfare state; this kind of endogeneity causes a positive bias in a simple OLS regression. On the other hand, it may be impossible to find appropriate instruments for civicness in survey data. A further complication is caused by the fact that both individuals' support for the welfare state and their civicness are measured by categorical variables.

To address the unavailability of instruments, we followed procedure 18.1 of Wooldridge (2002), which consists of two steps: (a) estimate an ordered response model for civicness, $P(w=m \mid \mathbf{x})=P(\mathbf{x} ; \gamma)$ by maximum likelihood, where $w$ represents the variable capturing civicness, $m$ is one of the possible five choices, $\gamma$ is a vector of parameters to be estimated and $\mathbf{x}$ is a number of relevant controls. Obtain the fitted probabilities $\hat{P}_{i} ;(b)$ use $\hat{P}_{i}$ as an instrumental variable (IV) in a TSLS regressing support for the welfare state, $y$, on $w$ and $\mathbf{x}$. This procedure has been proven to produce consis- 
tent estimates and asymptotically valid standard errors and test statistics. Because $P(\mathbf{x} ; \gamma)$ is a nonlinear function of $\mathbf{x}$, it is not perfectly correlated with $\mathbf{x}$, so it can be used as an instrument for $w$; in addition, the model for $P(\mathbf{x} ; \gamma)$ does not have to be correctly specified. Support to this choice is provided in the literature by Cerulli (2014), among others, who refers to this procedure as probit-TSLS. ${ }^{6}$ We are aware that this identification strategy is not as straightforward and transparent as the exploitation of a natural experiment. However, we believe it is anyway preferable to a basic OLS approach because it uses the same estimator employed in experimentbased IV strategies, which at least has been proven to be consistent in large samples. Wooldridge (2002) showed that, given the validity of instruments, probit-TSLS and the more conventional IV strategy provide the same result in large samples. To cope with possible small sample bias, we use the Limited Information Maximum Likelihood (LIML) estimator as a correction mechanism in robustness checks. LIML, in fact, has the same large sample distribution as TSLS, but provides finite sample bias reduction.

As the interpretation of the empirical analysis is basically derived from the coefficient of the interacted term between taxpayers' civic capital and their perception of the probability of being caught and sanctioned for tax evasion, we instrumented both civicness and the interaction term between civicness and the perceived probability of being caught.

The categorical nature of our variables of interest, both dependent and independent, deserves further attention. As far as the dependent is concerned, $y$, when the regression equation has a limited dependent variable (LDV) nonlinear models like logit or probit are invoked. In the past, some authors had recommended accounting for the categorical nature of the dependent variable in the specification of the models in the two stages (e.g. Amemiya, 1978; Blundell and Smith, 1989; Newey, 1987; Rivers and Vuong, 1988). However, the seminal work of Angrist (2001) showed that difficulties with LDV models are usually more apparent than real, as the causal relationship between $w$ and $y$ can be consistently estimated by means of a linear TSLS. Furthermore, when an independent endogenous variable, $w$, measured by a discrete indicator

\footnotetext{
${ }^{6}$ In particular, probit-TSLS is an option of the Stata command ivtreatreg.
} 
Table 1: Dependent: support for the welfare state

\begin{tabular}{|c|c|c|c|c|c|c|c|}
\hline VARIABLES & $\begin{array}{l}(1) \\
\text { OLS }\end{array}$ & $\begin{array}{c}(2) \\
\text { TSLS }\end{array}$ & $\begin{array}{c}(3) \\
\text { TSLS }\end{array}$ & $\begin{array}{c}(4) \\
\text { TSLS }\end{array}$ & $\begin{array}{c}(5) \\
\text { TSLS }\end{array}$ & $\begin{array}{c}(6) \\
\text { TSLS }\end{array}$ & $\begin{array}{c}(7) \\
\text { LIML }\end{array}$ \\
\hline civicness & $\begin{array}{l}0.0190^{* *} \\
(0.00828)\end{array}$ & $\begin{array}{c}-0.517^{* *} \\
(0.225)\end{array}$ & $\begin{array}{c}-0.537^{* *} \\
(0.225)\end{array}$ & $\begin{array}{c}-0.640^{* * *} \\
(0.247)\end{array}$ & $\begin{array}{c}-0.523^{* *} \\
(0.226)\end{array}$ & $\begin{array}{c}-0.491^{* *} \\
(0.210)\end{array}$ & $\begin{array}{c}-0.521^{* *} \\
(0.227)\end{array}$ \\
\hline civic $^{*}$ pr fine & $\begin{array}{l}-0.00208 \\
(0.00289)\end{array}$ & $\begin{array}{l}0.191^{* *} \\
(0.0819)\end{array}$ & $\begin{array}{l}0.191^{* *} \\
(0.0812)\end{array}$ & $\begin{array}{l}0.199^{* *} \\
(0.0880)\end{array}$ & $\begin{array}{l}0.193^{* *} \\
(0.0826)\end{array}$ & $\begin{array}{l}0.177^{* *} \\
(0.0777)\end{array}$ & $\begin{array}{l}0.192^{* *} \\
(0.0828)\end{array}$ \\
\hline pr of fine & $\begin{array}{l}-0.0109 \\
(0.0262)\end{array}$ & $\begin{array}{c}-1.695^{* *} \\
(0.715)\end{array}$ & $\begin{array}{c}-1.700^{* *} \\
(0.708)\end{array}$ & $\begin{array}{c}-1.773^{* *} \\
(0.769)\end{array}$ & $\begin{array}{c}-1.713^{* *} \\
(0.721)\end{array}$ & $\begin{array}{c}-1.564^{* *} \\
(0.678)\end{array}$ & $\begin{array}{c}-1.708^{* *} \\
(0.723)\end{array}$ \\
\hline gender & $\begin{array}{l}-0.00818 \\
(0.00998)\end{array}$ & $\begin{array}{l}-0.0107 \\
(0.0125)\end{array}$ & $\begin{array}{l}-0.0109 \\
(0.0125)\end{array}$ & $\begin{array}{l}-0.0156 \\
(0.0130)\end{array}$ & $\begin{array}{l}-0.0108 \\
(0.0125)\end{array}$ & $\begin{array}{l}-0.0115 \\
(0.0121)\end{array}$ & $\begin{array}{l}-0.0107 \\
(0.0125)\end{array}$ \\
\hline age & $\begin{array}{c}0.00118^{* * *} \\
(0.000387)\end{array}$ & $\begin{array}{c}0.00151^{* * *} * \\
(0.000514)\end{array}$ & $\begin{array}{c}0.00156^{* * *} \\
(0.000528)\end{array}$ & $\begin{array}{c}0.00187^{* * *} \\
(0.000535)\end{array}$ & $\begin{array}{c}0.00153^{* * * *} \\
(0.000512)\end{array}$ & $\begin{array}{c}0.00137^{* * * *} \\
(0.000480)\end{array}$ & $\begin{array}{c}0.00151^{* * *} \\
(0.000516)\end{array}$ \\
\hline househ. size & $\begin{array}{c}-0.0126^{* * *} \\
(0.00473)\end{array}$ & $\begin{array}{c}-0.0142^{* *} \\
(0.00615)\end{array}$ & $\begin{array}{l}-0.0142^{* *} \\
(0.00625)\end{array}$ & $\begin{array}{l}-0.0137^{*} \\
(0.00699)\end{array}$ & $\begin{array}{l}-0.0139 * * \\
(0.00617)\end{array}$ & $\begin{array}{c}-0.0134^{* *} \\
(0.00594)\end{array}$ & $\begin{array}{c}-0.0142^{* *} \\
(0.00617)\end{array}$ \\
\hline income & $\begin{array}{c}1.28 \mathrm{e}-08 \\
(1.95 \mathrm{e}-07)\end{array}$ & $\begin{array}{l}-1.15 \mathrm{e}-07 \\
(4.07 \mathrm{e}-07)\end{array}$ & $\begin{array}{c}-4.68 \mathrm{e}-08 \\
(4.61 \mathrm{e}-07)\end{array}$ & $\begin{array}{c}1.61 \mathrm{e}-07 \\
(3.98 \mathrm{e}-07)\end{array}$ & $\begin{array}{l}-1.10 \mathrm{e}-07 \\
(4.07 \mathrm{e}-07)\end{array}$ & $\begin{array}{l}-1.76 \mathrm{e}-07 \\
(3.82 \mathrm{e}-07)\end{array}$ & $\begin{array}{l}-1.17 \mathrm{e}-07 \\
(4.10 \mathrm{e}-07)\end{array}$ \\
\hline employed & $\begin{array}{c}0.0221 \\
(0.0138)\end{array}$ & $\begin{array}{c}0.0123 \\
(0.0193)\end{array}$ & $\begin{array}{l}0.00959 \\
(0.0206)\end{array}$ & & $\begin{array}{c}0.0121 \\
(0.0193)\end{array}$ & $\begin{array}{c}0.0148 \\
(0.0183)\end{array}$ & $\begin{array}{c}0.0123 \\
(0.0194)\end{array}$ \\
\hline self empl. & $\begin{array}{c}-0.0464^{* *} \\
(0.0211)\end{array}$ & $\begin{array}{c}-0.0569^{* *} \\
(0.0258)\end{array}$ & $\begin{array}{c}-0.0560 * * \\
(0.0258)\end{array}$ & & $\begin{array}{c}-0.0571^{* *} \\
(0.0259)\end{array}$ & $\begin{array}{l}-0.0404 \\
(0.0265)\end{array}$ & $\begin{array}{c}-0.0570^{* *} \\
(0.0258)\end{array}$ \\
\hline unemployed & $\begin{array}{c}0.0182 \\
(0.0250)\end{array}$ & $\begin{array}{c}0.0367 \\
(0.0406)\end{array}$ & $\begin{array}{c}0.0307 \\
(0.0445)\end{array}$ & & $\begin{array}{c}0.0362 \\
(0.0407)\end{array}$ & $\begin{array}{c}0.0461 \\
(0.0374)\end{array}$ & $\begin{array}{c}0.0369 \\
(0.0409)\end{array}$ \\
\hline fairness & & & & & $\begin{array}{l}-0.00927 \\
(0.0105)\end{array}$ & & \\
\hline tax evasion & & & & & & $\begin{array}{c}0.0731^{* *} \\
(0.0306)\end{array}$ & \\
\hline Constant & $\begin{array}{c}0.627 * * * \\
(0.0838)\end{array}$ & $\begin{array}{c}5.305^{* * *} \\
(1.966)\end{array}$ & $\begin{array}{c}5.483^{* * *} \\
(1.962)\end{array}$ & $\begin{array}{c}6.390^{* * *} \\
(2.152)\end{array}$ & $\begin{array}{c}5.388^{* * *} \\
(1.971)\end{array}$ & $\begin{array}{c}4.779 * * * \\
(1.799)\end{array}$ & $\begin{array}{c}5.337^{* * * *} \\
(1.985)\end{array}$ \\
\hline $\begin{array}{l}\text { Observations } \\
\text { Hansen- }(p)\end{array}$ & 8,703 & $\begin{array}{l}8,703 \\
0.722\end{array}$ & 8,703 & $\begin{array}{l}8,703 \\
0.158\end{array}$ & $\begin{array}{l}8,703 \\
0.716\end{array}$ & $\begin{array}{l}8,703 \\
0.661\end{array}$ & $\begin{array}{l}8,703 \\
0.723\end{array}$ \\
\hline
\end{tabular}

Robust standard errors in parentheses, ${ }^{* * *} \mathrm{p}<0.01,{ }^{* *} \mathrm{p}<0.05,{ }^{*} \mathrm{p}<0.1$.

Additional controls: regional dummies, education, civil status

is also considered, Angrist's claim still holds true. In fact, the prediction of a nonlinear first-stage can produce inconsistent IV estimates if the model is not correctly specified, as only the OLS estimation of the first-stage is guaranteed to produce firststage residuals that are uncorrelated with fitted values and covariates. It follows that a nonlinear first-stage is not necessary, or even not desirable, to the point that some authors refer to it as the "forbidden regression" (Angrist and Pishcke 2009, 143).

\subsection{Results}

Table 1 reports the results of the empirical application. 
Column (1) reports the OLS estimate in which civicness is treated as exogenous. In this case the estimate shows a positive relationship between civicness and support for the welfare state. This result, however, is likely to be inconsistent due to the positive bias caused by the endogeneity problems described above. To further test the endogeneity of civicness we performed a Durbin-Wu-Hausman test, which rejects the null of exogeneity at $1 \%$, prompting us to turn to the TSLS estimator. As explained in Section 3.2, instruments are $\hat{P}_{i}$ taken from the ordered probit of civicness on the other covariates. More specifically, as civicness takes on ten classes we can have up to nine potential instruments for civicness and a similar reasoning applies to its interaction with the probability of being punished in case of cheating. In the estimate reported in column (2), our benchmark, we have taken the first two $\hat{P}_{i}$ 's of the firststage of civicness plus the first $\hat{P}_{i}$ of the second first-stage, i.e. the one attaining the interaction term between civicness and the probability of being caught in case of tax evasion. We have chosen to keep the number of instruments at a minimum in order to perform a test of the validity of the instruments, i.e. Hansen $J$, without weakening its power, on this point see Roodman (2009). The Hansen $J$ statistic does not reject the null of the validity (p-value 0.722). Diagnostics of underidentification and weak identification have also been performed for each endogenous regressor separately, using the method described by Angrist and Pischke (2009, 217-218). In this case we cannot accept the null of underidentification and weak identification at $1 \%$, thus supporting the consistency of the estimated coefficients. In addition, the first-stage estimates show significant correlation between the instruments and the instrumented variables at $1 \%$ and $5 \%$ for civiceness and its interaction, respectively. Yet, the LIML estimation is used to correct for small sample bias and it shows virtually no differences with respect to the benchmark. Column (2) reports the equivalent specification of the OLS performed with TSLS. Once endogeneity is accounted for, the variables of interest flip sign; civicness is now negatively and significantly correlated with support for the welfare state, consistently with Algan et al. (2016). This suggests that civic-minded individuals want less extensive welfare programs, probably because they are concerned with the free riding and rent seeking activities possibly carried out by fellow taxpayers. Uncivic individuals, on the other hand, express a higher support 
for the welfare state, probably because they are less concerned with the higher taxes needed to fund welfare schemes and because they hope to extract rents from them. The difference between OLS and TSLS may be read in the light of the presence of a large and positive bias in an OLS estimate, for the reasons put forth in Section 3.2. The interaction term between civicness and the perceived probability of being caught in case of tax evasion, on the other hand, is significantly positive. This suggests that once civic and uncivic individuals confront themselves with the possibility of being punished by surveillance institutions that can perform unexpected tax inspections, we observe a shift in their support for the welfare state. This may be explained by the fact that civic individuals are now more confident that free riding and rent seeking activities will be monitored and properly punished so, as predicted by Proposition 2, they express a higher support for the welfare state. Uncivic citizens, on the other hand, may be less confident in their ability to cheat on taxes and to obtain undue rents from public protection schemes, and therefore express lower support for welfare spending. The perceived probability that dishonest behaviors will be sanctioned, which is a proxy for the perceived efficiency of surveillance institutions, has a significant and negative association with individuals' support for the welfare state. This result, which must be handled with caution due to the endogeneity issues discussed in Section 3.2, suggests that taxpayers actually account for enforcement institutions in the determination of their optimal taxes, and that their opinions on public spending programs are significantly affected by their perceived ability to elude taxes. The lower is the perceived efficiency and tigthness of surveillance institutions, the higher may be the preference for welfare spending. This result is in line with the gist of Algan et al.'s (2016) arguments, to the extent that it takes into account the role of dishonesty in shaping people's support for the welfare state. As for the controls, support for the welfare state significantly increases with age. In addition to individuals' approaching retirement, this result may be related to worsening health conditions, which, unfortunately, we were unable to control for in the dataset. Self-employed workers show lower support for the welfare state. Self-employment has traditionally been associated with greater economic individualism and concomitant resistance to the welfare state. Expressions of the hostility of the self-employed to the state in general and to 
the welfare state in particular abound in Italy and elsewhere (see the seminal work of Wilensky, 1975, and the empirical findings in Torgler, 2003, and Alesina and La Ferrara, 2005, among others).

As a robustness check, we controlled for the possible role of respondents' beliefs regarding fairness of opportunities and self- and exogenous-determination (column 5). Fong (2011) showed that beliefs about self- and exogenous-determination are strong predictors of support for redistribution in the United States. To measure beliefs about self-determination we used responses to the following question: "Have you ever asked relatives or friends and acquaintances to help you or a member of your household find work or deal with government red tape (e.g. speed up formalities)?". We interpret the fact of relying on personal contacts, instead of personal abilities and skills, as a sign of the belief that achieving results in life partly depends on potentially exogenous factors - such as the luck of being born in the right family. In addition we controlled for an indicator of the perceived seriousness of tax evasion (column 6) by using responses to the question: "Generally speaking, among the problems facing the Government, that of tax evasion is (choose one of the following items): non existent, marginal, the same as any other, serious, very serious". While the sign and significance of the estimates do not change, we interestingly observe a significant and positive correlation between the perceived seriousness of tax evasion and support for the welfare state. This result suggests that supporters of the welfare state are indeed concerned with the possibility of free-riding on taxes and rent-seeking on welfare benefits by their fellow citizens, and that tighter surveillance institutions may induce a more truthful revelation of the preferences of civic-minded individuals. As a further robustness check, we removed one instrument from the set, column (3), an operation that did not significantly affect the estimate.

\section{Conclusions}

In this article we studied how civic capital shapes support for the welfare state in an environment where, following Guiso et al. (2006; 2010; 2016) and Algan et al. (2016), taxpayers are defined either as "civic" or "uncivic" based on their attitudes towards 
actions aimed at obtaining private benefits at a social cost. Following Algan et al. (2016), we assumed that some individuals can hide their income to free-ride on taxes and to claim welfare benefits they are not entitled to. For example, while employees whose income tax is deducted from the pay slip have no choice but declaring their actual income, retail dealers can choose not to issue receipts in order to hide their actual revenues. This decision basically depends on the concrete possibility of hiding income and on the civic capital of individuals. We added to the literature by explicitly modelling the possibility that tax surveillance institutions can detect and punish uncivic individuals who have the possibility of hiding their income and choose to do so. In this case, rational taxpayers internalize the probability of being caught and the penalties due in case of tax evasion. Our results showed that when tax surveillance is tight, uncivic individuals support the welfare state less than their civic-minded fellow citizens. In absence of penalties for tax evasion, on the other hand, civic taxpayers want less welfare spending than uncivic ones. Of course we do not make any normative assumption equating civic-mindedness with support for big government and a welfare state. Rather, we show that the difference between civic and uncivic individuals' support for the welfare state can vary depending on the institutional context, in ways that were not previously theorized and tested in the literature. After controlling for endogeneity issues, the empirical analysis provided support for the predictions of the model. Overall, our results suggest that the efficiency of enforcement institutions might play a critical role in inducing a more truthful revelation of the preferences of taxpayers. More in general, the legitimacy and the political and financial sustainability of the welfare state could be improved through the establishment of tighter rules on tax surveillance and through long-term policies that strengthen the civic spirit of citizens.

\section{References}

[1] Aghion, P., Algan, Y., Cahuc, P. Shleifer, A. (2010). Regulation and distrust. Quarterly Journal of Economics 125(3), 1015-1049.

[2] Alesina, A., La Ferrara, E. (2005). Preferences for Redistribution in the Land 
of Opportunities. Journal of Public Economics 89, 897-931.

[3] Algan, Y., Cahuc, P. (2010). Inherited Trust and Growth. American Economic Review, 100(5), 2060-2092.

[4] Algan, Y., Cahuc, P. (2016). Trust, Growth and Well-being: New Evidence and Policy Implications. In Durlauf, S.N., Aghion, P. (Eds). Handbook of Economic Growth. Amsterdam: Elsevier.

[5] Algan, Y., Cahuc, P., Sangnier, M. (2016). Trust and the Welfare State: The Twin Peaks Curve. The Economic Journal, 126(593): 861-883.

[6] Andriani, L. (2016). Tax morale and prosocial behaviour: evidence from a Palestinian survey. Cambridge Journal of Economics, 40(3): 821-841.

[7] Amemiya T. (1978). The estimation of a simultaneous equation generalized probit model. Econometrica, 46, 1193-1205.

[8] Amemiya T. (1979). The estimation of a simultaneous-equation tobit model. International Economic Review, 20, 169-181.

[9] Angrist, J.D., Pishke, J.S. (2009). Mostly Harmless Econometrics: An Empiricist's Companion. Princeton University Press, Princeton.

[10] Antoci, A., Sabatini, F., Sodini, M. (2012). The Solaria Syndrome: Social Capital in a Hypertechnological Growing Economy. Journal of Economic Behavior and Organization 81 (3), 802-814.

[11] Bénabou, R., Ok, E. A. (2001). Social Mobility and the Demand for Redistribution. Quarterly Journal of Economics 116 (2), 447-487.

[12] Bergh, A., Bjørnskov, C. (2011). Historical levels of trust predict the current size of the welfare state. Kyklos 64(1), 1-19.

[13] Bigoni, M., Bortolotti, S., Casari, M., Gambetta, D., Pancotto, F. (2016). Amoral Familism, Social Capital, or Trust? The Behavioural Foundations of the Italian North-South Divide. The Economic Journal, 126(594): 1318-1341. 
[14] Bjørnskov, C., Svendsen, G. T. (2013). Does social trust determine the size of the welfare state? Evidence using historical identification. Public Choice 157, 269-286.

[15] Blundell R. W, Smith R.J. (1989). Estimation in a Class of Simultaneous Equation Limited Dependent Variable Models. Review of Economic Studies, 56, 37-58.

[16] Bourdieu, P., 1980. Le capital social. Actes de la Recherche en Sciences Sociales $31,2-3$.

[17] Cerulli G. (2014). ivtreatreg: A command for fitting binary treatment models with heterogeneous response to treatment and unobservable selection. Stata Journal, 14(3), 453-480.

[18] Coleman, J. (1988). Social capital in the creation of human capital. American Journal of Sociology 94, S95-S120.

[19] Coleman, J. (1990). Foundations of social theory. Cambridge, MA, and London, UK: Harvard University Press.

[20] Corneo, G., Gruner, H. P. (2002). Individual preferences for political redistribution. Journal of Public Economics 83, 83-107.

[21] Daniele, G., Geys, B. (2015). Interpersonal trust and welfare state support. European Journal of Political Economy 39, 1-12.

[22] Fine, B. (2001). Social capital versus social theory. London: Routledge.

[23] Fong, C. (2001). Social preferences, self-interest, and the demand for redistribution. Journal of Public Economics 82, 225-246.

[24] Feld, L., Frey, B.S. (2002). Trust Breeds Trust: How Taxpayers Are Treated. Economics of Governance 3, 87-99.

[25] Frey, B.S., Torgler, B. (2007). Tax morale and conditional cooperation. Journal of Comparative Economics 35, 136-159.

[26] Gelissen, J. P. T. M., van Oorschot W. J. H., Finsveen, E. (2012). How does the welfare state influence individuals' social capital? European Societies iFirst 2012, 1-25. 
[27] Guiso, L., Sapienza, P., Zingales, L. (2006). Does Culture Affect Economic Outcomes? Journal of Economic Perspectives 20(2), 23-48.

[28] Guiso, L., Sapienza, P., Zingales, L. (2009). Cultural biases in economic exchange. Quarterly Journal of Economics 124(3), 1095-1131.

[29] Guiso, L., Sapienza, P., Zingales, L. (2011). Civic capital as the missing link. In Benhabib, J., Bisin, A., Jackson, M. (Eds). Handbook of Social Economics. Amsterdam: Elsevier.

[30] Guiso, L., Sapienza, P., Zingales, L. (2016). Long term persistence. Journal of the European Economic Association, 14-6: 1401-1436.

[31] Kumlin, S., Rothstein, S. (2005). Making and breaking social capital. Comparative Political Studies 38 (4), 339-365.

[32] Lewbel, A. (2012). Using heteroscedasticity to identify and estimate mismeasured and endogenous regressor models. Journal of Business and Economic Statistics, 30(1), 67-80.

[33] Meltzer, A. H., Richard, S. F. (1981). A Rational Theory of the Size of Government. Journal of Political Economy 89(5), 914-927.

[34] Newey W.K. (1987). Efficient estimation of limited dependent variable models with endogenous explanatory variables. Journal of Econometrics, 36, 231-250.

[35] Piketty, T. (1995). Social Mobility and Redistributive Politics. Quarterly Journal of Economics 110(3), 551-584.

[36] Putnam, R.D., Leonardi, R., Nanetti, R.Y. (1993). Making democracy work. Civic traditions in modern Italy. Princeton: Princeton University Press.

[37] Rivers D., Vuong Q.H. (1988). Limited information estimators and exogeneity tests for simultaneous probit models. Journal of Econometrics 39, 347-366.

[38] Roodman D. (2009). A Note on the theme of too may instruments. Oxford Bulletin of Economics and Statistics, 71(1): 135-158. 
[39] Rothstein, B. (2002). Sweden. Social Capital in the Social Democratic State. The Swedish Model and Civil Society. In Robert D. Putnam (ed). Democracies in Flux. Political Culture as a Condition for Democracy. Oxford: Oxford University Press.

[40] Rothstein, B. (2009). The universal welfare state. In Svendsen, G.T. and Svendsen, G.L. (ed). Handbook of social capital. The troika of sociology, political science and economics. Cheltenham: Edward Elgar.

[41] Sabatini, F. (2007). The Empirics of Social Capital and Economic Development: a Critical Perspective. In Osborne, M., Sankey, K. e Wilson, B. (eds). Social Capital, Lifelong Learning Regions and the Management of Place: an international perspective. London and New York, Routledge.

[42] Sabatini, F. (2009). Social Capital as Social Networks: a New Framework for Measurement and an empirical analysis of its determinants and consequences. Journal of Socio-Economics, 38 (3), 429-442.

[43] Sabatini, F. , Sarracino, F., Yamamura, E. (2014). Social norms on rent seeking and preferences for redistribution. MPRA Paper 57151.

[44] Torgler, B. (2003). Tax Morale, Rule-Governed Behaviour and Trust. Constitutional Political Economy 14, 119-140.

[45] Woolcock, M. (1998). Social capital and economic development: Toward a theoretical synthesis and policy framework. Theory and Society 27(2), 151-208.

[46] Wooldridge J.M. (2002). Econometric Analysis of Cross Section and panel Data. MIT Press, Cambridge, Massachusets, London, England.

[47] Yamamura, E. (2012). Social capital, household income, and preferences for income redistribution. European Journal of Political Economy, 28(4), 498-511. 